УДК 342.9

DOI https://doi.org/10.32837/pyuv.v0i3(32).601

\author{
P.I. Лемеха \\ orcid.org/0000-0001-9013-8318 \\ кандидат юридичних наук, \\ здобувач наукового ступеня доктора юридичних наук \\ кафедри адміністративного та господарського права \\ Запорізького національного університету
}

\title{
ПРАВОВІ ЗАСАДИ МИТНИХ РЕЖИМІВ В УКРАЇНІ: СУЧАСНИЙ СТАН І НАПРЯМИ ВДОСКОНАЛЕННЯ
}

Вступ. Україна поступово розвивається як цивілізована європейська правова держава 3 ринковою економікою. В умовах жорсткої світової конкуренції важливим є створення сприятливих умов для розвитку міжнародної торгівлі, збільшення обсягів транзиту, експорту та імпорту товарів через митний кордон України, що забезпечить збільшення надходжень до Державного бюджету України, створення нових робочих місць на митній території України та сприятиме зростанню економіки країни.

Ключову роль у забезпеченні сприятливого інвестиційного клімату та привабливості національної економіки для суб'єктів зовнішньоекономічної діяльності відіграє якісний рівень правового забезпечення митних відносин, спрощення порядку переміщення товарів і транспортних засобів через митний кордон України. Це зумовлює актуальність та практичну значимість окремого наукового дослідження щодо правових засад митних режимів в Україні, які є комплексом взаємопов'язаних правових норм, що відповідно до заявленої мети переміщення товарів через митний кордон України визначають митну процедуру щодо цих товарів, їх правовий статус, умови оподаткування і зумовлюють їх використання після митного оформлення.

Дослідження правових засад митних режимів в Україні є основою для подальшого удосконалення чинного національного законодавства та юридичної практики, розробки перспективного законодавства у сфері правового регулювання митних режимів.

Питання адміністративно-правового регулювання митних відносин в Україні досліджуються в роботах фахівців у сфері адміністративного права, серед яких роботи О. Бандурки, В. Бевзенка, Н. Білак, М. Віхляєва, Н. Губерської, С. Гусарова, Р. Калюжного, Т. Коломоєць, В. Колпакова, А. Комзюка, О. Кузьменко, В. Курила, Д. Лук'янця, Д. Лученка, П. Лютікова, М. Мельника, Р. Мельника, О. Миколенка, Я. Назарової, Н. Нижник, Д. Приймаченка, С. Стеценко, М. Тищенка, О. Чуприни, А. Школика та інших вчених-адміністративістів.
Із останніх досліджень слід згадати дисертаційні роботи М. Мельника «Інститут митних режимів у митному праві України» [1], Н. Білак «Особливості переміщення об’єктів інтелектуальної власності через митний кордон України" [2], Я. Назарової «Правове регулювання митних режимів тимчасового ввезення та тимчасового вивезення» [3], О. Чуприни «Правове регулювання митних режимів переробки" [4] та його наукову публікацію «Класифікація митних режимів у юридичній науці та законодавстві» [5]. Проте питання правових засад митних режимів в Україні досліджено фрагментарно, здебільшого в рамках більш загальних тем, що актуалізує проведення цього дослідження.

Методологія дослідження грунтується на комплексному поєднанні філософських, загальнонаукових (прийомів логічного методу, системного та структурно-функціонального методів) i спеціально-юридичних методів дослідження (методу юридичної догматики, методу юридичного моделювання, методології порівняльного правознавства), принципів об'єктивності та історизму.

Постановка завдання. Метою наукової публікації є дослідження сучасного стану та перспективних напрямів удосконалення правових засад митних режимів в Україні.

Результати дослідження. Розпочинаючи дослідження правових засад митних режимів в Україні, слід визначити ієрархію нормативно-правових актів, які регулюють митні відносини. Вищу юридичну силу та пряму дію мають норми Конституції України, які закріплюють основні права і свободи людини, принципи та порядок організації та діяльності органів публічної адміністрації.

Правова регламентація та практична реалізація митних режимів насамперед здійснюється 3 урахуванням закріплених у Конституції України принципів права, серед яких ключове значення має принцип верховенства права, що включає в себе три взаємопов'язані елементи: принцип верховенства прав і свобод людини, принцип верховенства ратифікованих Верховною Радою України норм міжнародного права над нормами національного права, а також принцип конституційності, 
тобто верховенства норм Конституції над нормами інших нормативно-правових актів.

Другу позицію за юридичною силою в ієрархії нормативно-правових актів посідають ратифіковані Верховною Радою України міжнародно-правові акти, одним із етапів ратифікації яких є перевірка на відповідність положенням Конституції України, яку здійснює Конституційний Суд України. Фундаментальне значення для національної юридичної практики мають рішення Європейського суду з прав людини, прийняті на основі та на виконання європейської Конвенції про захист прав та основоположних свобод людини.

Враховуючи правову природу митних режимів, комплексний міжгалузевий характер цього правового інституту митного права, норми міжнародних договорів у сфері міжнародної торгівлі та митної справи є одним із основних джерел права в системі правових засад митних режимів. Зокрема, прямо пов'язані із митними режимами умови поставки товарів на експорт та імпорт, визначені Міжнародною торговою палатою в правилах Iнкотермс, які виступають єдиним набором міжнародних правил для однозначного тлумачення найбільш уживаних торговельних термінів у зовнішній торгівлі.

Третю сходинку в ієрархї̈ правових засад митних режимів в Україні посідає Митний кодекс України, який безпосередньо встановлює види митних режимів (ст. 70 Митного кодексу України), регламентує порядок вибору та зміни митного режиму (ст. 71), визначає митний статус товарів, що поміщуються у митний режим (ст. 72), а також регулює інші питання, пов'язані із відповідним митним режимом.

На цьому ж рівні за юридичною силою знаходяться закони України, які регулюють окремі питання, пов'язані із митними режимами: Закони України «Про зовнішньоекономічну діяльність», «Про Митний тариф України» тощо. Проте основним нормативно-правовим актом, який регулює суспільні відносини у сфері правового регулювання митних режимів на рівні закону, $\epsilon$ Митний кодекс України. Норми інших законів, які регулюють окремі питання зовнішньоекономічної діяльності, не повинні суперечити положенням Митного кодексу України.

Важливе місце в ієрархії правових основ митної справи загалом і митних режимів зокрема посідають постанови Касаційних судів у складі Верховного Суду та постанови Великої Палати Верховного Суду (четверта ланка в ієрархіі), які містять правові позиції (висновки) вищого органу судової влади щодо правильного застосування норм матеріального і процесуального права. Де-факто вони є судовими прецедентами, тобто принципами розгляду судом певної юридичної справи, які засто- совуються при розгляді всіх аналогічних справ у майбутньому.

Суди нижчих інстанцій можуть не врахувати висновки щодо застосування норм права, викладені у постановах Верховного Суду, проте такі випадки зустрічаються нечасто. Таким чином, Верховний Суд фактично здійснює судову правотворчість у сфері правового регулювання митних відносин, здійснюючи казуальне тлумачення норм права та формуючи висновки щодо їх правильного застосування.

Так, Касаційний адміністративний суд у складі Верховного суду розмежував поняття «митний контроль» i «митне оформлення» (Постанова Верховного Суду від 18 січня 2018 року у справі № 807/3168/14). У вказаній справі позивач оскаржував дії працівників митного поста щодо проведення переогляду транспортного засобу з вантажем і його затримку через проведення додаткових перевірочних заходів [6].

Верховний Суд у складі колегії суддів Касаційного адміністративного суду вважає помилковими доводи скаржника, що митний контроль є складником митного оформлення при переміщенні товарів, транспортних засобів через митний кордон України, оскільки ці дві правові категорії (митний контроль і митне оформлення) відрізняються за своїм змістом і є двома різними процесами, які мають власні системні характеристики.

Відповідно до ст. 4 Митного кодексу України митне оформлення - це виконання митних формальностей, необхідних для випуску товарів, транспортних засобів комерційного призначення. Митний контроль - сукупність заходів, що здійснюються з метою забезпечення додержання норм цього кодексу, законів та інших нормативно-правових актів з питань державної митної справи, міжнародних договорів України, укладених у встановленому законом порядку [7].

Згідно з приписами ст. 321 Митного кодексу України товари, транспортні засоби комерційного призначення перебувають під митним контролем з моменту його початку і до закінчення згідно із заявленим митним режимом. У разі вивезення товарів, транспортних засобів комерційного призначення за межі митної території України митний контроль закінчується після здійснення їх митного оформлення та перетинання ними митного кордону України, за винятком митних режимів, які передбачають перебування під митним контролем протягом усього часу дії митного режиму [7].

На підставі наведених норм колегія суддів дійшла висновку, що під митним контролем товари, транспортні засоби комерційного призначення перебувають з моменту заявлення митного режиму (шляхом подання митної декларації) до фактичного перети- 
нання ними митного кордону України (отримання дозволу від митного органу) [6]. Таким чином, навіть після завершення митного оформлення товару, яке в цьому випадку було здійснено на внутрішньому митному посту, митні органи у пункті пропуску на митному посту уповноважені були здійснювати митний контроль товару шляхом проведення передбачених Митним кодексом України контрольно-перевірочних заходів до фактичного перетинання таким товаром митного кордону України.

На підставі викладеного суд касаційної інстанції зазначив, що суди першої та апеляційної інстанцій при обгрунтуванні рішень помилково виходили з того, що митний контроль включає також митне оформлення, оскільки ці правові категорії не співвідносяться як загальне та окреме, проте це не вплинуло на правильність прийнятих судових рішень у зазначеній справі [6].

Заслуговує на увагу практика Верховного Суду щодо спорів, які виникають при визначенні митними органами вищої ціни товарів, ніж заявляється імпортерами при ввозі товару в Україну.

Як зазначає А. Паркулаб, лише з моменту вступу в силу нових процесуальних кодексів (15.12.2017) по 17.11.2019 судами розглянуто приблизно 3000 справ, в яких оскаржуються рішення митниць про коригування митної вартості. Верховним Судом розглянуто приблизно 400 касаційних скарг із цієї категорії справ [8].

Передумовою спорів, на думку А. Паркулаба, $€$ як недосконалість Митного кодексу, так і постійні намагання уряду в ручному режимі збільшувати надходження до бюджету з митниць шляхом запровадження негласних індикативних цін, «таблиць», профілів ризику тощо. Оскільки таке ручне регулювання несумісне з положеннями Митного кодексу, на рівні Верховного Суду сформувалася здебільшого позитивна практика для імпортерів. Виключенням стала постанова Верховного Суду від 30.10.2018 по справі № 816/2396/17.

Здебільшого обставини справ, у яких розглядається правомірність рішень про коригування митної вартості, є типовими і повторюються від справи до справи. Імпортер заявляє до митного оформлення товар, вартість якого визначає за першим методом (за ціною контракту). Митний орган із тих чи інших підстав не визнає заявлену митну вартість, приймає рішення про коригування митної вартості і відмовляє в митному оформленні за заявленою митною вартістю. Далі у імпортера, який не згодний із прийнятими рішеннями, але бажає якнайшвидше отримати товари, є два варіанти дій: самостійно сплатити митні платежі з ціни, визначеної митним органом, і в подальшому, в разі скасування рішень, вимагати їх повернення, або надати фінансові гарантії сплати різниці митних платежів між ціною, визначеною імпортером, і ціною, визначеною митним органом. У фінансових гарантій є два істотні недоліки: їх можуть видавати тільки уповноважені і внесені до реєстру гарантів юридичні особи (лише п'ять гарантів у реєстрі станом на 16.07.2019), а максимальний строк гарантії складає 90 днів. Якщо за 90 днів рішення про коригування митної вартості не скасовується, імпортер буде змушений сплатити різницю митних платежів [8].

А. Паркулаб зазначає, що отримати за 90 днів рішення суду про скасування рішення про коригування митної вартості, яке набрало законної сили, не можливо навіть теоретично. У зв'язку 3 цим у більшості випадків після відмови у митному оформленні за заявленою ціною імпортери подають нову митну декларацію із ціною, визначеною митним органом, сплачують різницю митних платежів, а далі вже оскаржують рішення про коригування митної вартості, а в разі успіху повертають різницю.

Те, яким чином імпортер здійснював митне оформлення після прийняття рішення, не мало жодного значення при вирішенні питання щодо правомірності рішень про коригування митної вартості товарів під час судового розгляду і ніколи особливо не цікавило суди. Але в постанові Верховного Суду від 30.10.2018 по справі № 816/2396/17 суд висловив новий погляд на звичні речі.

Згідно із вказаним рішенням, подання нової митної декларації з ціною, визначеною митним органом, свідчить про згоду декларанта з такою ціною, а тому правовий спір між сторонами вичерпано внаслідок погодження декларанта із митною вартістю, визначеною митним органом, а у задоволенні позову про скасування рішення про коригування митної вартості слід відмовити. Єдиним варіантом поведінки, яка свідчить про незгоду декларанта з визначеною митним органом вартістю та надає можливість у подальшому оскаржувати рішення в суді, за позицією суду залишається надання фінансових гарантій відповідно до ч. 7 ст. 55 Митного кодексу [8]. Таким чином, Верховний Суд у вказаному рішенні відступив від усталеної судової практики. В той же час факти відступу судів нижчих інстанцій від правових позицій Верховного Суду за усталеною практикою зустрічаються нечасто.

П'яту сходинку в ієрархії правових засад митних режимів посідають укази Президента України та постанови Кабінету Міністрів України, які вже є підзаконним актами, що приймаються до виконання на основі та відповідно до Конституції і законів України. Основою для нормотворчості Президента і уряду у сфері правового регулювання митних режимів насамперед є Конституція та Митний кодекс України, які визначають обсяг їх нормотворчих повноважень і межі їх засто- 
сування. Прикладом нормотворчої діяльності Президента України у сфері правового регулювання митних відносин є Указ Президента України «Про Державну митну службу України» від 29 листопада 1996 року № 1145/96 у редакції від 30.04.2011 [9].

Кабінет Міністрів України відповідно до Конституції України здійснює правове забезпечення організації та діяльності Державної митної служби України, врегульовує питання, пов'язані із застосуванням митних декларацій, а також інші питання, пов'язані з переміщенням товарів і транспортних засобів через митний кордон України, їх митним оформленням та використанням.

Серед ключових нормативно-правових актів, які відносяться до правових засад митних режимів в Україні, належать Постанова КМУ № 227 від 06.03.2019 «Про затвердження положень про Державну податкову службу України та Державну митну службу України» [10]; Постанова КМУ № 450 від 21.05.2012 «Питання, пов’ язані із застосуванням митних декларацій», якою затверджено Положення про митні декларації [11], Постанова КМУ № 295 від 27.03.2013 «Про деякі питання перебування товарів у митному режимі переробки на митній території України, обмеження і заборони щодо поміщення окремих товарів у зазначений митний режим і визнання такими, що втратили чинність, деяких актів Кабінету Міністрів України» [12].

На шостій сходинці ієрархії нормативно-правових актів, які регулюють окремі питання митних режимів в Україні, знаходяться відомчі підзаконні нормативно-правові акти, а саме накази міністерств і Державної митної служби України. Це Наказ Міністерства фінансів України від 04.08.2015 № 693 «Про діяльність митних брокерів» у редакції від 22.02.2019 [13] та Наказ Державної митної служби України від 17.11.2005 № 1118 «Про затвердження Правил митного контролю та митного оформлення транспортних засобів, що переміщуються громадянами через митний кордон України» у редакції від 18.09.2009 [14].

У відомчих нормативно-правових актах положення законів, постанов уряду максимально деталізуються, і завдяки досить простій процедурі прийняття наказів органи публічної адміністрації мають можливість оперативно реагувати на зміни у суспільних відносинах, вирішувати нагальні питання їх адміністративно-правового регулювання. Накази є універсальними підзаконними нормативно-правовими актами, якими затверджуються відповідні порядки, інструкції, положення, стандарти, нормативи, тарифи та форми документів. Проте необхідність дотримання принципів верховенства права та правової визначеності вимагає від публічної адміністрації надавати перевагу законодавчому врегулюванню більшості питань, пов'язаних із правовим регулюванням митних режимів в Україні. Саме тому основним джерелом права в такому випадку $є$ Митний кодекс України, правова матерія якого доповнюється практикою Верховного Суду, яка по суті має прецедентний характер.

Висновки. Дослідження правових засад митних режимів в Україні дозволяє сформулювати висновок про те, що основою правового регулювання митних режимів є Конституція України, міжнародні нормативно-правові акти, ратифіковані Верховною Радою України, Митний кодекс України та закони України у сфері правового регулювання митних відносин, Укази Президента України та постанови Кабінету Міністрів України, накази міністерств і Державної митної служби України.

Суттєве значення для національної юридичної практики у сфері правового регулювання митних режимів мають рішення Європейського суду 3 прав людини, прийняті на основі та на виконання європейської Конвенції про захист прав та основоположних свобод людини. Враховуючи правову природу митних режимів, комплексний міжгалузевий характер цього правового інституту митного права, норми міжнародних договорів у сфері міжнародної торгівлі та митної справи є одними 3 основних джерел права у системі правових засад митних режимів.

Важливу роль у правовому регулюванні митних відносин відіграють постанови Верховного Суду (Касаційного адміністративного суду у складі Верховного Суду), в яких містяться правові позиції щодо правильного застосування норм матеріального та процесуального права.

Актуальним напрямом удосконалення правових засад митних режимів в Україні є завершення процесу приведення національного законодавства та юридичної практики у сфері правового регулювання митних режимів у відповідність до міжнародних стандартів з урахуванням перспектив набуття Україною повноправного членства у Свропейському Союзі. Удосконалення потребує Митний кодекс України, про недоліки якого свідчить неоднозначна адміністративна та судова практика. Не менш важливим є формування усталеної судової практики розгляду справ, пов'язаних із митними режимами, на рівні Постанов Великої Палати Верховного Суду з метою забезпечення однакового застосування норм матеріального та процесуального права національними судами.

Перспектива подальшого дослідження 3 цієї тематики зумовлена постійними змінами до національного законодавства у сфері правового регулювання митних режимів, які вимагають науко- 
вого узагальнення, а також необхідністю розробки Концепції державної митної політики та Стратегії розвитку Державної митної служби України.

\section{Jimepamypa}

1. Мельник М.В. Інститут митних режимів у митному праві України : дис. канд. юрид. наук: спец. 12.00.07 «Адміністративне право і процес; фінансове право; інформаційне право». Міжрегіональна академія управління персоналом. Київ, 2016. $251 \mathrm{c}$.

2. Білак Н.І. Особливості переміщення об'єктів інтелектуальної власності через митний кордон України : автореф. дис. канд. юрид. наук: спец. 12.00.07 «Адміністративне право і процес; фінансове право; інформаційне право». Міжнародний гуманітарний університет. Одеса, 2019. 25 с.

3. Назарова Я.Б. Правове регулювання митних режимів тимчасового ввезення та тимчасового вивезення : автореф. дис. канд. юрид. наук: спец. 12.00.07 «Адміністративне право і процес; фінансове право; інформаційне право». Національний юридичний університет імені Ярослава Мудрого. Харків, 2016. 20 c.

4. Чуприна О.В. Правове регулювання митних режимів переробки : автореф. дис. канд. юрид. наук: спец. 12.00.07 «Адміністративне право і процес; фінансове право; інформаційне право». Національний юридичний університет імені Ярослава Мудрого. Харків, 2015. 20 с

5. Чуприна О.В. Класифікація митних режимів в юридичній науці та законодавстві. Право та інноваиії. 2015. № 2(10). С. 133-139.

6 . Верховний суд розмежував поняття «митний контроль» $\mathrm{i}$ «митне оформлення» / Офіційний портал «Судова влада України». URL: https://court.gov.ua/ press/news/512072/.

7. Митний кодекс України від 13 березня 2012 року № 4495-VI. Дата оновлення: 19.06.2020. URL: https://zakon.rada.gov.ua/laws/show/4495-17\#Text.

8. Паркулаб А. Верховний суд ламає усталену практику у справах про коригування митної вартості? Протокол: юридичний інтернет-ресурс. Юридичний портал Протокол. Юридична дискусія. Статті. URL: https://protocol.ua/ua/verhovniy_sud_lamae_ ustalenu_praktiku_u_spravah_pro_koriguvannya mitnoi vartosti/.

9. Про Державну митну службу України : Указ Президента України від 29 листопада 1996 року № 1145/96. Дата оновлення: 30.04.2011. URL: https://zakon.rada.gov.ua/laws/show/1145/96\#Text.

10. Про затвердження положень про Державну податкову службу України та Державну митну службу України : постанова Кабінету Міністрів України від 06 березня 2019 року № 227. Дата оновлення: 29.07.2020. URL: https://zakon.rada.gov.ua/laws/show/227-2019$\% \mathrm{D} 0 \% \mathrm{BF} \#$ Text.

11. Положення про митні декларації, затверджене постановою Кабінету Міністрів України від 21 травня 2012 року № 450 . Дата оновлення: 07.08.2020. URL: https://zakon.rada.gov.ua/laws/show/450-2012$\% \mathrm{D} 0 \% \mathrm{BF} \#$ Text.

12. Про деякі питання перебування товарів у митному режимі переробки на митній території України, обмеження і заборони щодо поміщення окремих товарів у зазначений митний режим і визнання такими, що втратили чинність, деяких актів Кабінету Міністрів України : постанова Кабінету Міністрів України від
27 березня 2013 року № 295. Дата оновлення: 08.02.2020. URL: https://zakon.rada.gov.ua/laws/ show/295-2013-\% D0\% BF\#Text.

13. Про діяльність митних брокерів : наказ Міністерства фінансів України від 04.08.2015 № 693. Дата оновлення: 22.02.2019. URL: https://zakon.rada.gov.ua/laws/show/z1036-15\#Text.

14. Про затвердження Правил митного контролю та митного оформлення транспортних засобів, що переміщуються громадянами через митний кордон України : наказ Державної митної служби України від 17.11.2005 № 1118. Дата оновлення: 18.09.2009. URL: https://zakon.rada.gov.ua/laws/show/z1428-05\#Text.

\section{Анотація}

Лелеха $P$. I. Правові засади митних режимів в Україні: сучасний стан i напрями вдосконалення. - Стаття.

У науковій публікації досліджуються сучасний стан і напрями удосконалення правових засад митних режимів в Україні з урахуванням актуальної судової практики. Зазначається, що в умовах жорсткої конкуренції у сфері міжнародної торгівлі важливим $\epsilon$ створення сприятливих умов для суб'єктів зовнішньоекономічної діяльності, збільшення обсягів транзиту, експорту та імпорту товарів через митний кордон України, що забезпечить збільшення надходжень до Державного бюджету України, створення нових робочих місць на митній території України та сприятиме зростанню економіки України.

Дослідження правових засад митних режимів в Україні дозволяє сформулювати висновок про те, що основою правового регулювання митних режимів є Конституція України, міжнародні нормативно-правові акти, ратифіковані Верховною Радою України, Митний кодекс України та закони України у сфері правового регулювання митних відносин, укази Президента України та постанови Кабінету Міністрів України, накази міністерств і Державної митної служби України.

Важливу роль у правовому регулюванні митних відносин відіграють постанови Верховного Суду, в яких містяться правові позиції щодо правильного застосування норм матеріального та процесуального права. Актуальним напрямом удосконалення правових засад митних режимів в Україні є завершення процесу приведення національного законодавства та юридичної практики у сфері правового регулювання митних режимів у відповідність до міжнародних стандартів, враховуючи перспективи набуття Україною повноправного членства у Європейському Союзі.

Зазначається, що удосконалення потребує Митний кодекс України, про недоліки якого свідчить неоднозначна адміністративна та судова практика. Не менш важливим є формування усталеної судової практики розгляду справ, пов'язаних із митними режимами, на рівні постанов Великої Палати Верховного Суду з метою забезпечення однакового застосування норм матеріального та процесуального права національними судами.

Формулюється висновок про перспективність подальшого доктринального дослідження цієї тематики з урахуванням постійних змін до національного законодавства у сфері правового регулювання митних режимів, які вимагають наукового узагальнення, а також необхідність розробки Концепції державної митної політики та розвитку Державної митної служби України. 
Ключові слова: митний режим, правові засади, міжнародні акти, судова практика, правова позиція, міжнародні стандарти, митне оформлення, митний контроль, усталена практика.

\section{Summary}

Lemekha $R$. I. Legal bases of customs regimes in Ukraine: current state and directions of improvement. Article.

The scientific publication is devoted to the current state and areas of improvement of the legal bases of customs regimes in Ukraine, taking into account current case law. It is noted that in conditions of fierce competition in international trade it is important to create favorable conditions for foreign economic activity, increase transit, export and import of goods across the customs border of Ukraine, which, accordingly, will increase revenues to the State Budget of Ukraine, create new jobs in the customs territory of Ukraine and in general will contribute to the growth of Ukraine's economy.

The study of legal bases of customs regimes in Ukraine allows to formulate the conclusion that the basis of legal regulation of customs regimes is the Constitution of Ukraine, international regulations ratified by the Verkhovna Rada of Ukraine, the Customs Code of Ukraine and laws of Ukraine in the field of legal regulation of customs relations and resolutions of the Cabinet of Ministers of Ukraine, orders of ministries and directly of the State Customs Service of Ukraine.
An important role in the legal regulation of customs relations is played by the rulings of the Supreme Court, which contain legal positions on the correct application of substantive and procedural law. An urgent area of improving the legal framework of customs regimes in Ukraine is to complete the process of bringing national legislation and legal practice in the field of legal regulation of customs regimes in line with international standards, given the prospects of Ukraine's full membership in the European Union.

It is noted that the Customs Code of Ukraine needs to be improved, the shortcomings of which are evidenced by ambiguous administrative and judicial practice. Equally important is the establishment of established case law on customs regimes at the level of the Grand Chamber of the Supreme Court in order to ensure the uniform application of substantive and procedural law by national courts.

The conclusion on the prospects of further doctrinal research on this topic is formulated, taking into account the constant changes in national legislation in the field of legal regulation of customs regimes that require scientific generalization, as well as the need to develop the Concept of State Customs Policy and Development of the State Customs Service of Ukraine.

Key words: customs regime, legal bases, international acts, judicial practice, legal position, international standards, customs clearance, customs control, established practice. 